\title{
Trace Metal Concentrations in Pine Needles at Varying Elevation in Proximity to Roadways in an Urban Environment
}

\author{
Graham Brown, Isabella Luu, Gwen 0'Sullivan* \\ Department of Earth \& Environmental Science, Mount Royal University, Calgary, Canada \\ Email: ^gosullivan@mtroyal.ca
}

How to cite this paper: Brown, G., Luu, I. and O'Sullivan, G. (2017) Trace Metal Concentrations in Pine Needles at Varying Elevation in Proximity to Roadways in an Urban Environment. Journal of Environmental Protection, 8, 733-743.

https://doi.org/10.4236/jep.2017.86047

Received: May 9, 2017

Accepted: June 25, 2017

Published: June 28, 2017

Copyright (c) 2017 by authors and Scientific Research Publishing Inc. This work is licensed under the Creative Commons Attribution International License (CC BY 4.0).

http://creativecommons.org/licenses/by/4.0/

\begin{abstract}
Conifer needles bioaccumulate atmospheric pollutants, including trace metals, and may be used to monitor variations in atmospheric concentration. Needles were analyzed to determine whether a correlation exists between elevations and trace metal concentrations in proximity to roadways and other non-point sources. Composite samples of white spruce (Picea glauca) and balsam fir (Abies balsamea) needles were collected along hillsides in eastern and western Calgary, respectively. A combined total of 11 sites was sampled along two transects of increasing elevation. Qualitative and quantitative analysis of trace metal concentrations was completed using inductively coupled plasma-mass spectrometry (ICP-MS) and synthesized using regression analysis. The concentrations of cobalt, nickel, and calcium in the samples were found to exhibit a significant $(\mathrm{P}<0.05)$ relationship with respect to elevation and proximity to roadways.
\end{abstract}

\section{Keywords}

Trace Metal Deposition, Biomonitoring, Non-Point Sources, Atmospheric Deposition

\section{Introduction}

Tree species can bioaccumulate polluting particles from the atmosphere due to their distinct biological characteristics, contributing to the regulation of pollutants present in the atmosphere and are having been shown to be suitable in monitoring trace metals [1] [2]. Research on this subject indicates that the use of conifer needles in monitoring metal concentrations is an effective biomonitoring technique of atmospheric pollution [2]. Previous studies indicate that pine needles can accumulate elevated levels of trace metals beyond the concentrations 
that are crucial for biological growth [2]. Guardo et al. (2003) shown that conifer needles have additional resin channels enabling the uptake of metals and can be more effective in accumulating compounds relative to broad-leafed species. The use of spatial and temporal trends in atmospheric uptake has been used to establish concentrations gradients with respect to the distance from point sources [3]. Non-point sources, such as traffic, contribute to the variation in trace metal concentrations found in conifer needles [4]. External sources such as emissions and soil dusts can significantly affect the metal concentration accumulation on pine needle surfaces [5]. Furthermore, infrastructure, such as roads and buildings often increases the wind turbulence that may enhance the capture of particulates in the atmosphere [6].

Numerous studies have demonstrated variance in trace metal uptake by species necessitating the need for uniform sampling [3] [7] [8] [9]. No literature regarding the use of $P$. glauca for biomonitoring is available while, $A$. balsamea is documented to be an effective species for determining atmospheric concentrations of trace metals through needle analysis [10]. Beckett et al. (2000) [6] indicated an increase in the capture efficiency of atmospheric pollutants with intricate branch compositions and numerous smaller needles. Atmospheric pollutant trends can also be determined as bioaccumulation is highest near the point source and gradually declines from the point of source [3]. Previous studies concerning elevation have been focused in alpine environments at elevations ranging from $1300 \mathrm{~m}$ to $1800 \mathrm{~m}$ where positive statistical correlations were observed [11]. The purpose of this study was to identify and quantify 28 trace metal concentrations in pine tree at varying elevations and proximity to roadway in an urban environment as a means to differentiate between natural and anthropogenic sources.

\section{Materials \& Methods}

\subsection{Study Sites}

Mayland Heights ( $P$. glauca) and the Valley Ridge-Bow River pathway ( $A$. balsamea) in the eastern and western areas of the City of Calgary, Alberta, Canada, were selected s locations to examine $P$. glauca and $A$. balsamea as biomonitoring indicators. Site locations were selected based on 1) consistent coniferous species with respect to its elevation, 2) the presence of non-point sources (e.g., roadways), and 3) accessibility.

\subsubsection{Mayland Heights Site}

Mayland Heights is situated northeast of a major city traffic source, Highway No. 2 (Deerfoot Trail). This expressway is heavily congested during rush hours, typically in the morning and late afternoon, which is in part due to commuters heading Northbound and Southbound through Calgary. Lower traffic roadways to the southeast and north of the sampling locations are present at higher elevations, while Highway No. 2 adjoins with the lowest elevation sampling point. Pine needles were collected from six locations ranging from elevations of $1037 \mathrm{~m}$ 
to $1066 \mathrm{~m}$, and located downwind of the northeasterly winds relative to location 2 (Figure 1, Table 1).

\subsubsection{Valley Ridge-Bow River Pathway Site}

The Valley Ridge -Bow River pathway is situated on the western edge of Calgary, south of the Bow River and north of the Trans-Canada Highway. The TransCanada Highway exhibits persistent traffic throughout the day, as it one of the dominant longitudinal transit ways through Calgary. Highway 201 (Stoney Trail NW) is situated east of the study area with similar traffic volumes to Highway 1. The highest site altitude adjoins Highway 201, and each site was sampling point was located at decreasing elevations relative to this expressway (Figure 2, Table 1).

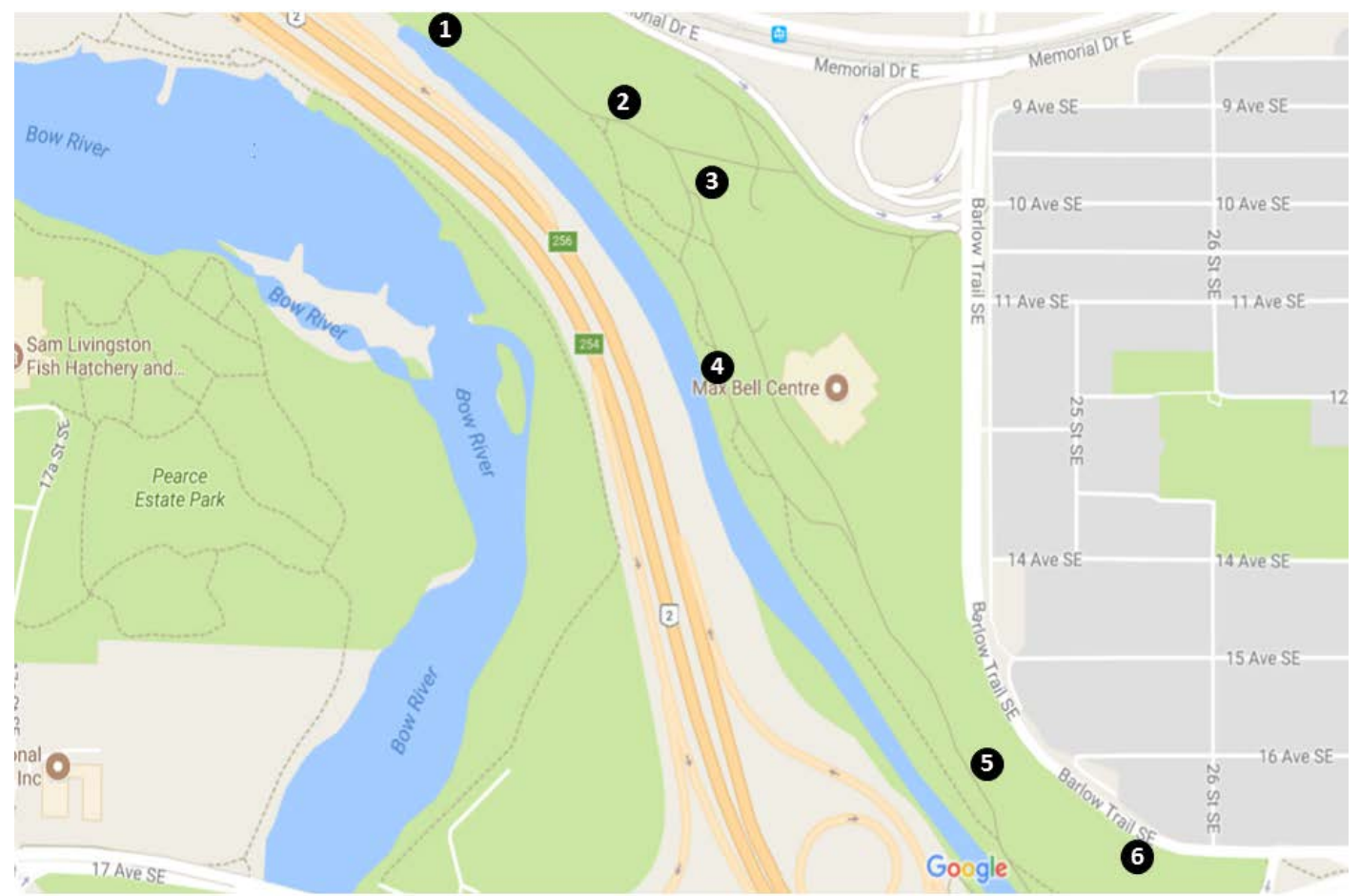

Figure 1. Location of sampling sites within Mayland Heights (East of Calgary).

Table 1. The elevation and distance from neighbouring expressway for each of the sample site within the two sample locations.

\begin{tabular}{ccccc}
\hline \multirow{2}{*}{ Location } & \multicolumn{2}{c}{ Mayland Heights } & \multicolumn{2}{c}{$\begin{array}{c}\text { Valley Ridge-Bow } \\
\text { River Pathway }\end{array}$} \\
\cline { 2 - 5 } & Elevation $(\mathrm{m})$ & Distance $(\mathrm{m})$ & Elevation $(\mathrm{m})$ & Distance $(\mathrm{m})$ \\
\hline 1 & 1037 & 200 & 1095 & 40 \\
2 & 1047 & 250 & 1077 & 155 \\
3 & 1050 & 350 & 1097 & 10 \\
4 & 1043 & 150 & 1100 & 90 \\
5 & 1058 & 500 & 1116 & 55 \\
6 & 1066 & 530 & -- & -- \\
\hline
\end{tabular}




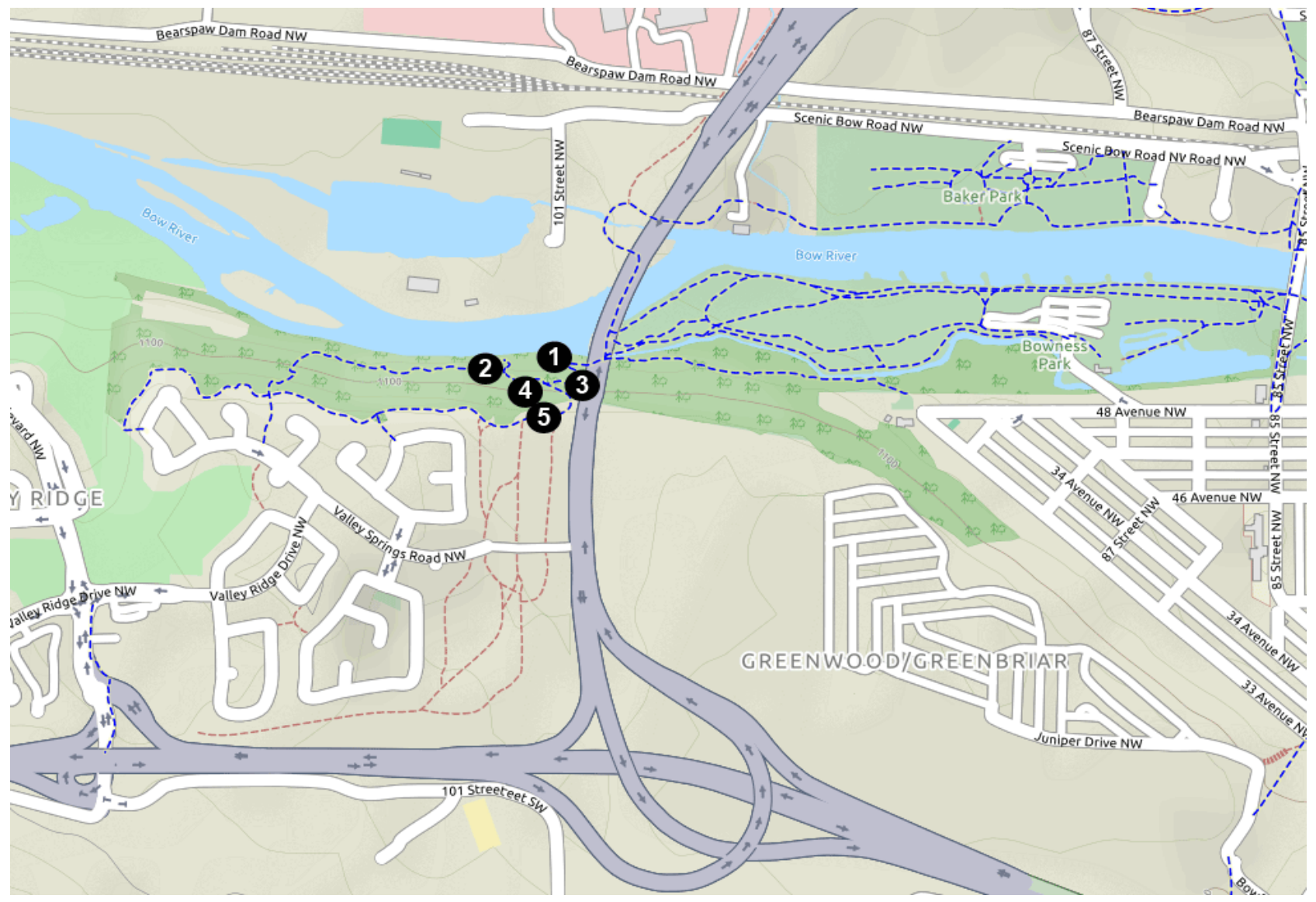

Figure 2. Location of sampling sites within Valley Ridge-Bow River pathway.

\subsection{Sample Collection \& Chemical Analysis}

Pine needles were collected from all cardinal directions at heights of 1 to 2 meters $(\mathrm{m})$ above the ground mature healthy trees displaying minimal foliage browning and signs of disease. Composite pine needle samples were collected by randomly selecting 2 to 3 individual trees at each site that were assumed to be representative of the study site. To test this assumption, a composite sample of needles at location 1 was collected with three additional samples from the individual trees.

Samples were collected on $24^{\text {th }} \& 26^{\text {th }}$ of February 2016. Each composite sample was collected by peeling needles from the branches while removing the cuticle, and transferring into a plastic sampling bag in the field. Each bag was labeled on-site with the location, elevation, and GPS coordinates. Sampling occurred on separate days to ensure exposure time prior to preservation was consistent between locations. The needle samples were transported to the laboratory and stored in a freezer at $-4^{\circ} \mathrm{C}$ to prevent biological decomposition.

Needles were prepared for analysis by stripping any remaining cuticles, mixing and drying in oven at $100^{\circ} \mathrm{C}$ for 16 hours. Two-grams of dried samples were then transferred into the Thermolyne F6000, Thermo Fisher Scientific (NC, USA) furnace for dry-ashing. Samples were heated at $6.6^{\circ} \mathrm{C} / \mathrm{min}$ to a final temperature of $400^{\circ} \mathrm{C}$ with a dwell of 24 hours to ensure complete removal of car- 
bon.

Following ashing, samples were digested using 10 millimeters (mls) of concentrated ultrapure nitric acid and $10 \mu \mathrm{l}$ of hydrogen peroxide for 24 hours. The supernatant was diluted with deionized water and analysis of trace metal concentrations was completed with Inductively Coupled Plasma-Mass Spectrometry (ICP-MS). The ICP-MS was performed with an X Series 2 Thermo Fisher Scientific (MA, USA). The ICP-MS was calibrated using stock solutions of Fe, $\mathrm{K}, \mathrm{Ca}$, $\mathrm{Na}, \mathrm{Mg}$ for calibration and 10 parts per million (ppm) of $\mathrm{Ag}, \mathrm{Al}, \mathrm{As}, \mathrm{Ba}, \mathrm{Be}, \mathrm{Cd}$, $\mathrm{Co}, \mathrm{Cr}, \mathrm{Cu}, \mathrm{Mn}, \mathrm{Mo}, \mathrm{Ni}, \mathrm{Pb}, \mathrm{Sb}, \mathrm{Se}, \mathrm{Tl}, \mathrm{V}, \mathrm{Zn}$, Th, $\mathrm{U}$ in $10 \% \mathrm{HNO}_{3}$, Agilent), an internal standard (single element standard, $10 \mu \mathrm{g} / \mathrm{mL} \mathrm{Rh}$ in $2 \% \mathrm{HCl}$, Agilent) and a pine needle certified reference material (CRM-PN-A, High-purity standards Inc.). Each sample was analyzed six times and to ensure precision of data (data tightly clustered around the mean), analysis was repeated if the relative standard deviation was greater than $2 \%$.

\subsection{Statistical Analysis}

Statistical analysis of elemental concentrations contained in the needle samples was completed using regression analysis and repeated measures of variance (ANOVA). Data quality analysis was completed and outliers observed within the dataset were discarded with $98 \%$ confidence using the t-test. Pearson's correlation coefficient $(r)$ was used to establish a relationship between elevations and trace metal concentration.

\section{Results \& Discussion}

The range and mean concentration of 15 trace metals detected in the needles of P. glauca (Mayland Heights) and A. balsamea (Valley Ridge-Bow River pathway) conifer species are summarized in Table 2. Higher concentrations were exhibited at Mayland Heights and it is assumed that variation in traffic congestion may account for differences in metal concentration ranges for the two study areas. Mayland Heights was surrounded by major roadways with daily traffic flows of 169,000 and 79,000 vehicles relative to the 51,000 daily traffic flow adjacent to Valley Ridge-Bow River pathway [12]. Possible additional compounding factors include the northeasterly winds that pass through the city and their ability to carry certain trace metals distances up to 200 kilometers $(\mathrm{km})$ [13], thereby increasing trace metal concentrations downwind of the source [3] [14].

\subsection{Correlations}

Three of the 28 trace metals analyzed displayed a statistically significant correlation between elevation and concentration $(\mathrm{P}<0.05)$, indicated by Pearson's correlation coefficient. The analysis of variance of $\mathrm{Ca}, \mathrm{Ni}$, and $\mathrm{Co}$ are shown in $\mathrm{Ta}$ ble 3.

\subsubsection{Cobalt}

Concentrations of cobalt ranged from $0.18( \pm 0.004)$ milligrams per kilogram 
Table 2. Ranges and mean values (ppm) of 15 trace metals from pine needs collected at two sampling sites.

\begin{tabular}{ccccc}
\hline & \multicolumn{2}{c}{ Maryland Heights } & \multicolumn{2}{c}{ Valley Ridge-Bow River Pathway } \\
\cline { 2 - 5 } $\mathrm{Na}$ & Range (min-max) & Mean & Range (min-max) & Mean \\
$\mathrm{Mg}$ & $723-1215$ & 1803 & $139-679$ & 392 \\
$\mathrm{~K}$ & $1087-1615$ & 1352 & $1037-1682$ & 4086 \\
$\mathrm{Ca}$ & $4242-7218$ & 5742 & $2950-4887$ & 8981 \\
$\mathrm{Mn}$ & $5980-9911$ & 8740 & $4960-13,771$ & 35 \\
$\mathrm{Fe}$ & $17-39$ & 28 & $17-82$ & 73 \\
$\mathrm{~V}$ & $105-157$ & 131 & $50-99$ & 0.29 \\
$\mathrm{Co}$ & $0.41-0.57$ & 0.51 & $0.18-0.45$ & 0.18 \\
$\mathrm{Ni}$ & $0.18-0.24$ & 0.21 & $0.09-0.30$ & 0.85 \\
$\mathrm{Cu}$ & $0.68-1.00$ & 0.87 & $0.57-1.06$ & 2.54 \\
$\mathrm{Zn}$ & $3.28-5.51$ & 4.29 & $1.89-3.26$ & 45.1 \\
$\mathrm{Mo}$ & $22.8-82.1$ & 52.9 & $24.6-67.9$ & 0.45 \\
$\mathrm{Sb}$ & $0.68-1.73$ & 1.15 & $0.18-0.56$ & 0.02 \\
$\mathrm{Ba}$ & $0.07-0.17$ & 0.11 & $0.01-0.03$ & 56.5 \\
$\mathrm{~Pb}$ & $38.1-104.8$ & 70.3 & $22.0-123.6$ & 0.46 \\
\end{tabular}

Table 3. Perason's correlation coffients $(r)$ and $\mathrm{p}=$ values for trace metal concentration relative to elevation.

\begin{tabular}{cccc}
\hline & Mayland Site & Bow River pathway Site & p-value \\
\hline Cobalt & -0.890 & - & 0.0175 \\
Nickel & - & 0.887 & 0.0448 \\
Calcium & - & 0.908 & 0.0331 \\
\hline
\end{tabular}

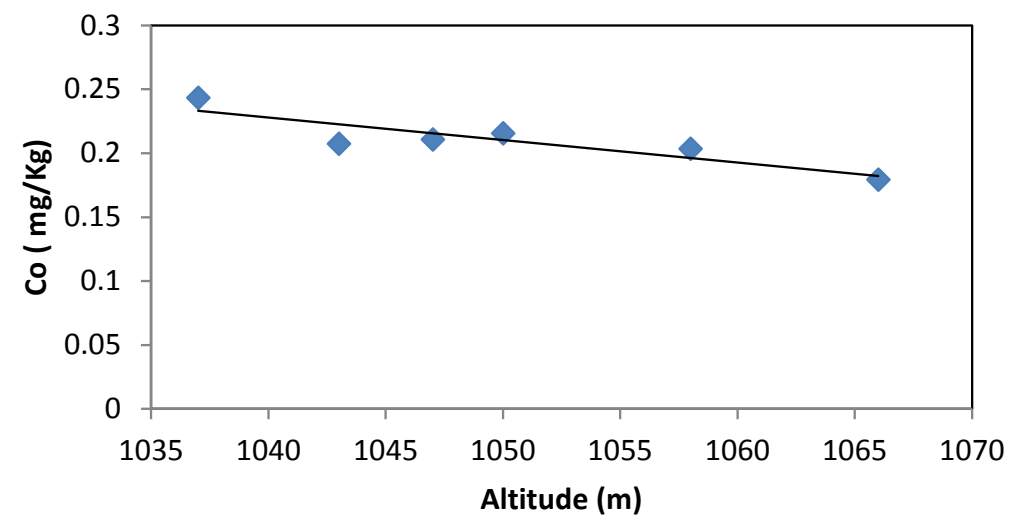

Figure 3. Concentrations obtained for cobalt at Mayland Heights are statistically significant with respect to elevation $(P=0.0175$. Approximately $79 \%$ of the variation is explained by the elevation $\left(\mathrm{R}^{2}=79.18 \%\right.$, average standard deviation $= \pm 0.004)$.

$(\mathrm{mg} / \mathrm{Kg})$ at the highest altitude of $1066 \mathrm{~m}$ to $0.24( \pm 0.009) \mathrm{mg} / \mathrm{Kg}$ at the lowest altitude of $1037 \mathrm{~m}$ at Mayland Heights (Figure 3). A negative correlation between cobalt concentrations with respect to altitude $\left(\mathrm{P}<0.05, \mathrm{R}^{2}=0.79184\right)$ was observed mirroring the trend identified by Lin and Schuepp (1995) in A. balsamea [10]. 
The linear relationship between altitude and trace-metal concentration suggests the highest concentrations are directly correlated to the increased traffic volume associated with Deerfoot Trail relative to surrounding non-point sources. Major anthropogenic sources of cobalt in the environment are typically associated with industry and mining operations [13]. The Mayland Heights study area is upwind of the major industrial sector in eastern Calgary. Although there are no cobalt mines present within $330 \mathrm{~km}$ of Calgary; low amounts of cobalt are present in vehicle emissions and attributed to the combustion of fossil fuels [15].

Preceding studies have shown that background levels of cobalt in plant tissue near roadways are generally $<1 \mathrm{ppm}$ and are largely attributed to metabolic processes in organisms at low concentrations [16], while uncontaminated areas range from 0.4 - 0.8 parts per trillion (ppt) [17]. The dominant intake method of cobalt is unclear, with its introduction through the root system favored [9] [18] and contested due to low transfer potential attributed to minimal bioavailability of cobalt [8]. Despite the correlation of cobalt with its proximity to roadways, a strong correlation $\left(\mathrm{R}^{2}<40 \%\right)$ between cobalt and other vehicle exhaust metals (copper, nickel and lead) was not found suggesting sources other than traffic exhaust were potential contributors. Additionally, spatial characteristics including tree spacing, surface area, and surrounding vegetation may affect the uptake or deposition of atmospheric particles [6].

\subsubsection{Nickel}

Nickel displayed a positive correlation $(\mathrm{P}<0.05)$ between concentrations with respect to elevation at Valley Ridge-Bow River site (Figure 4). Nickel is a common exhaust emission with concentrations decreasing with distances from roadways [4] [19] [20] [21] [22]; additional sources are linked to the tire-wear and deterioration of brake linings on vehicles [20]. Snowmelt beneath tree canopies has been correlated with increased nickel concentrations while in proximity to point-source pollution [23]. With exposure to the roadway increasing with elevation due to decreased foliage density, sites at higher elevations have snow

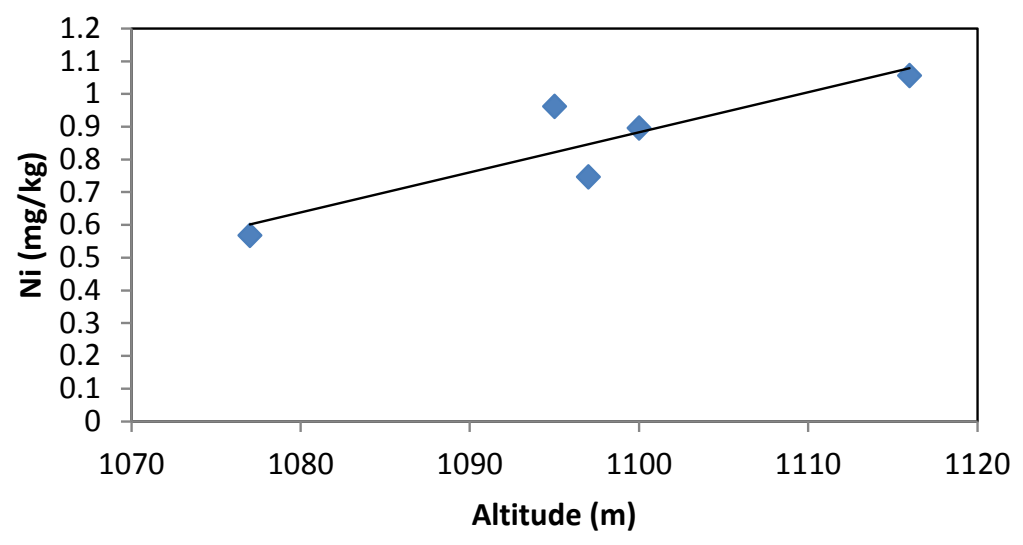

Figure 4. Concentrations obtained for nickel at Valley Ridge-Bow River pathway are statistically significant with respect to elevation $(P=0.04479)$. Approximately $79 \%$ of the variation is explained by the elevation $\left(R^{2}=78.68 \%\right.$ average standard deviation $= \pm 0.01$ ). 
piles more exposed to vehicle emissions that consequently melt and enter the soil profile and root system. Baseline studies in other regions have reported concentrations not exceeding $5 \mathrm{ppm}$ [17], with toxicity occurring at 10 - $15 \mathrm{ppm}$ [24].

When comparing the nickel concentrations to other potential elements from vehicle exhaust (e.g., copper and lead), a statistically significant correlation was not observed. The absence in appearance of uniform deposition of these elements may be related to their translocation within the tree. Copper and nickel are phloem-mobile elements and may be translocated from older to younger needles [5]. Additionally uptake of these elements may slow as the tree ages, so accumulation may be less in older trees/needles. As nickel is highly bioavailable, the observed concentrations may reflect the levels in the soil, as foliage is a sink from uptake in the root systems [17].

\subsubsection{Calcium}

Calcium concentrations from the Valley Ridge-Bow River site displayed a positive correlation $(\mathrm{P}<0.05)$ with elevation (Figure 5$)$. Calcium is associated with traffic sources, with concentrations expected to decrease sharply to background with distance from the roadway [4] [19] [20] [21] [22]. Previous bioindicator studies identified elevated concentrations of calcium in pine needles originating from road salts used for de-icing [21] which correlates to the sodium chloride and calcium chloride mix used by the City of Calgary [25].

The dominant source of calcium is linked to calcium carbonate in atmospheric dust particles and biogenic origins [26], with conifer species accumulating larger concentrations relative to other higher vegetation (plants having well-developed vascular tissues) [27]. Calcium is naturally present in conifer species as it acts as a regulator of stresses such as freezing conditions [28].

\section{Conclusions}

The main purpose of this study was to examine the influence of elevation on metal composition of pine needles in proximity to roadways as a means to differ-

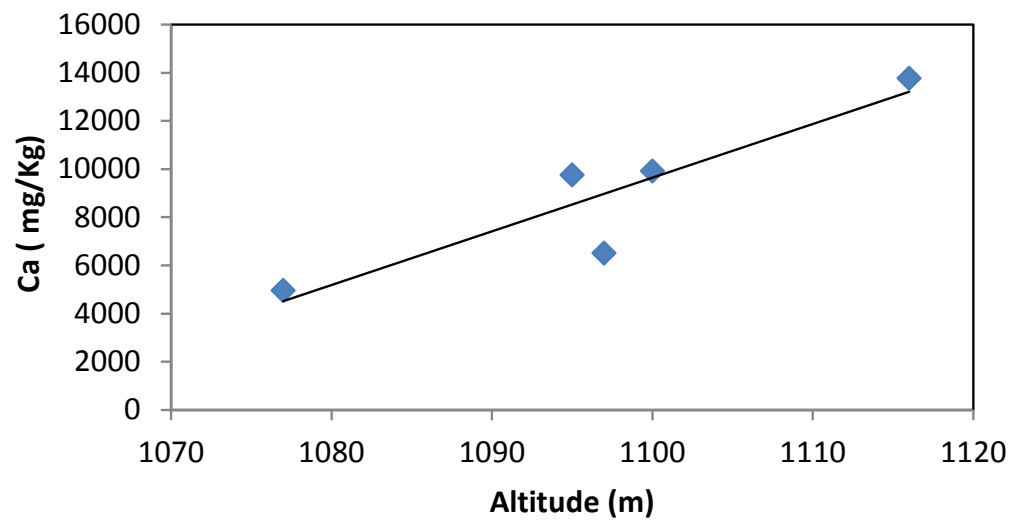

Figure 5. Results obtained for calcium at location 2 (Valley Ridge-Bow River pathway) is statistically significant with respect to altitude $(\mathrm{P}=0.0331)$. Approximately $82 \%$ of the variation of the concentration of calcium is explained by the elevation $\left(R^{2}=82.43 \%\right.$, average standard deviation $\left.= \pm 0.005\right)$. 
rentiate between natural and anthropogenic sources. With regards to elevation, a correlation between proximity to roadway and concentrations for cobalt, nickel and calcium is suggested. Variability between the two study locations was evident due to the proximity to roadways and varied daily with traffic volumes. However a combination of factors including uptake, translocation, and age of trees could affect trace metal bioaccumulation in conifer needles.

While the use of tree needles to examine the impact of trace metal and potential sources, the study highlights the need to understand the site specific conditions e.g. age of trees, soil properties and background concentrations at a location to determine contribution of atmospheric deposition (from both point and non-point emission sources) and soil uptake.

\section{Acknowledgements}

The author would like to thank Glenn Harahsym and Nadin Boegelsack for assistance in various aspects of the laboratory analysis. This study was funded by the Faculty of Science \& Technology at Mount Royal University.

\section{References}

[1] Beckett, K.P., Freer-Smith, P.H. and Taylor, G. (2003) Particulate Pollution Capture by Urban Trees: Effect of Species and Windspeed. Global Change Biology, 6, 9951003. https://doi.org/10.1046/j.1365-2486.2000.00376.x

[2] Forbes, P. (2015) Monitoring of Air Pollutants: Sampling, Sample Preparation and Analytical Techniques. Elsevier, USA.

[3] Guardo, A.D., Zaccara, S., Cerebolini, B., Acciarri, M., Terzaghi, G. and Calamari, D. (2003) Conifer Needles as Passive Biomonitors of the Spatial and Temporal Distribution of DDT from a Point Source. Chemosphere, 52, 789-797.

https://doi.org/10.1016/S0045-6535(03)00256-X

[4] Kord, B., Mataji, A. and Babaie, S. (2010) Pine (Pinus eldarica medw.) Needles as Indicator for Heavy Metals Pollution. International Journal of Science and Technology, 7, 79-84.

[5] Rautio, P. and Huttunen, S. (2003) Total vs. Internal Element Concentrations in Scots Pine Needles along a Sulphur and Metal Pollution Gradient. Environmental Pollution, 122, 273-289. https://doi.org/10.1016/S0269-7491(02)00289-0

[6] Beckett, K.P., Freer-Smith, P.H. and Taylor, G. (2000) Effective Tree Species for Local Air-Quality Management. Journal of Arboriculture, 26, 12-19.

[7] Aboal, J.R., Fernandez, J.A. and Carballeira, A. (2004) Oak Leaves and Pine Needles as Biomonitors of Airborne Trace Elements Pollution. Environmental and Experimental Biology, 51, 215-225. https://doi.org/10.1016/j.envexpbot.2003.11.003

[8] Gandois, L. and Probst, A. (2012) Localization and Mobility of Trace Metal in Silver Fir Needles. Chemosphere, 87, 204-210.

https://doi.org/10.1016/j.chemosphere.2011.12.020

[9] Ronggui, T., Ji, L., Peijun, Y., Jia, S., Youchao, C., Yiwen, G. and Jun, Z. (2014) Trace Metals of Needles and Litter in Timberline Forests in the Eastern of Tibetan Plateau, China. Ecological Indicators, 45, 669-676. https://doi.org/10.1016/j.ecolind.2014.06.003

[10] Lin, Z.Q. and Schuepp, H.P. (1995) Trace Metal Contamination in and on Balsam Fir (Abies balsamea (L) Mill.) Foliage in Southern Quebec, Canada. Water, Air and 
Soil Pollution, 81, 175-191. https://doi.org/10.1007/BF00477264

[11] Chropenova, M., Greguskova, E.K., Karaskova, P., Pribylova, P., Kukucka, P., Barakova, D. and Cupr, P. (2016) Pine Needles and Pollen Grains of Pinus mugo turra -A Biomonitoring Tool in High Mountain Habitats Identifying Environmental Contamination. Ecological Indicators, 66, 132-142. https://doi.org/10.1016/j.ecolind.2016.01.004

[12] City of Calgary (2015) Traffic Volume Flow Maps. http://www.calgary.ca/Transportation/TP/Pages/Planning/Transportation-Data/Tra ffic-volume-flow-maps.aspx

[13] Dunlap, C.E., Steinnes, E. and Flegal, R.A. (1999) A Synthesis of Lead Isotopes in Two Millennia of European Air. Earth and Planetary Science Letters, 167, 81-88. https://doi.org/10.1016/S0012-821X(99)00020-5

[14] Viard, B., Pihan, F., Promeyrat, S. and Pihan, J.-C. (2004) Integrated Assessment of Heavy Metal ( $\mathrm{Pb}, \mathrm{Zn}, \mathrm{Cd})$ Highway Pollution: Bioaccumulation in Soil, Graminaceae and Land Snails. Chemosphere, 55, 1349-1359. https://doi.org/10.1016/j.chemosphere.2004.01.003

[15] Umar, A., Yauri, B. and Muhammad, C. (2015) Acacia Nitolica as Bioindicator of Copper and Cobalt Pollution Due to Vehicular Emission along the Main Entrance Road of Usmanu Danfodiyo University, Sokoto-Nigeria. International Journal of Advanced Research in Chemical Science, 2, 1-8.

[16] Haneke, E.K. (2002) Toxicological Summary for Cobalt Dust [7440-48-4]. Integrated Laboratory Systems. https://ntp.niehs.nih.gov/ntp/htdocs/chem_background/.../cobaltdust_508.pdf

[17] Waldron, H.A. (1980) Metals in the Environment. Science of the Total Environment, 20, 287-287.

[18] Adriano, D.C. (2001) Trace Elements in Terrestrial Environments-Biogeochemistry, Bioavailability, and Risks of Metals. Springer-Verlag, New York. https://doi.org/10.1007/978-0-387-21510-5

[19] Ndiokwere, C. (1984) Heavy Metal Pollution from Vehicle Emission and Its Effect on Vegetable and Crops in Nigeria. Journal of Environmental Pollution, 7, 35-42.

[20] Ball, D.J., Hamilton, R.S. and Harrison, R.M. (1991) The Influence of Highway-Related Pollutants on Environmental Quality. Journal of Trace Elements in Medicine and Biology, 11, 176-178.

[21] Viskara, E.-L. and Karenlampi, L. (1999) Roadside Scots Pine as an Indicator of Deicing Salt Use-A Comparative Study from Two Consecutive Winters. Water, Air, and Soil Pollution, 122, 405-419. https://doi.org/10.1023/A:1005235422943

[22] Tomasevic, M., Anicic, M., Jovanovic, L., Peric-Grujic, A. and Ristic, M. (2011) Deciduous Tree Leaves in Trace Elements Biomonitoring: A Contribution to Methodology. Ecological Indicators, 11, 1689-1695. https://doi.org/10.1016/j.ecolind.2011.04.017

[23] Ershov, V.V., Lukina, N.V., Orlova, M.A. and Zukert, N.V. (2016) Dynamics of Snowmelt Water Composition in Conifer Forests Exposed to Airborne Industrial Pollution. Russian Journal of Ecology, 47, 46-52. https://doi.org/10.1134/S1067413616010045

[24] Marschner, P. (1995) Marschner's Mineral Nutrition of Higher Plants. 3rd Edition, Academic Press, Cambridge.

[25] City of Calgary (2016) Salt Management Plan. http://www.calgary.ca/Transportation/Roads/Pages/.../Salt-management-plan-FAQ $\underline{\text { s.aspx }}$ 
[26] Lehndorff, E., Urbat, M. and Schwark, L. (2006) Accumulation Histories of Magnetic Particles on Pine Needles as Function of Air Quality. Atmospheric Environment, 40, 7082-7096. https://doi.org/10.1016/j.atmosenv.2006.06.008

[27] Franceschi, V.R. and Nakata, P.A. (2006) Calcium Oxalate in Plants: Formation and Function. Annual Reviews of Plant Biology, 56, 41-71. https://doi.org/10.1146/annurev.arplant.56.032604.144106

[28] DeHayes, D.H., Schaberg, P.G., Hawley, G.J. and Strimbeck, R.G. (1999) Acid Rain Impacts on Calcium Nutrition and Forest Health Alteration of Membrane-Associated Calcium Leads to Membrane Destabilization and Foliar Injury in Red Spruce. BioScience, 49, 789-800. https://doi.org/10.2307/1313570

Submit or recommend next manuscript to SCIRP and we will provide best service for you:

Accepting pre-submission inquiries through Email, Facebook, LinkedIn, Twitter, etc. A wide selection of journals (inclusive of 9 subjects, more than 200 journals) Providing 24-hour high-quality service User-friendly online submission system Fair and swift peer-review system Efficient typesetting and proofreading procedure Display of the result of downloads and visits, as well as the number of cited articles Maximum dissemination of your research work

Submit your manuscript at: http://papersubmission.scirp.org/

Or contact jep@scirp.org 